\title{
A Critical Evaluation of articles Related to Islamic Banking
}

\author{
Yaaseen Masvood
}

\begin{abstract}
Islamic banking is any banking activity carried out within the parameters of Islamic jurisprudence. It differs from the traditional banking business in its prohibition of dealing with interest i.e. borrowing and lending of money for interest. Another feature that distinguishes Islamic banking is the concept of profit and loss sharing paradigm. These features have made this sunrise industry to not only attract new markets but also to show consistent growth over the years. Hence, large conventional banks have also shown interest in venturing into Islamic banking and have opened Islamic banking windows in their commercial set up in order to capitalize on the opportunity. Although Islamic banking is still in its nascent stage, it has become a global force to reckon with due to its strong ethical values and risk-minimization principles. The primary aim of this article is to critically review the existing literature available in studies related to Islamic banking.
\end{abstract}

Index Terms: Islamic banking, Islamic Finance, Interest-free, Selection criteria, Patronage factors

\section{INTRODUCTION}

Islamic banking works in accordance with the laws of Islamic jurisprudence. Islamic banking, an offshoot of Islamic Finance, is a new phenomenon in the financial industry and has gained significance in the recent times. It has emerged as one of the fastest growing industries in the world and has come to stay in the global market place. Islamic banking works in harmony with the rules of Islam and the principles of economic development. It is based on the principle of profit-risk sharing and hence seeks for a just and equitable distribution of resources. Hence it has been accepted as a viable alternative to traditional interest-based commercial banking because of its ethical values. The offerings of Islamic banking are not restricted to the Muslim community alone and hence it has got acceptance from the non-Muslim populace, across the globe. This is evident from the fact that large conventional banks are found offering a window of Islamic finance in the traditional set-up. Islamic banking offers a wide variety of its products and services and is considered a promising business in the global financial services industry, in the years to come.

This review contains the following four sections.

1. General studies that were carried out on Islamic banking.

2. Studies related to awareness and attitude towards Islamic banking

3. Studies related to bank patronage or bank selection criteria.

4.Studies related to the need, scope, growth potential, feasibility and prospects of Islamic banking in India.

Revised Manuscript Received on July 05, 2019

Dr. Yaaseen Masvood, SRM Institute of Science and Technology, Kattankulathur, Chennai, Tamizhnadu, India.

\section{GENERAL STUDIES ON ISLAMIC BANKING}

The concept and practice of Islamic Finance has been in practice from the time of Prophet Muhammad (Peace and Blessings of Allah be upon him). But, the first transaction of formal Islamic banking took place at Mit Ghamr in Egypt during 1963 only. Islamic Banking can be termed as banking activity following the principles laid out in the Islamic jurisprudence. As Muslims are prohibited from dealing with interest, they are not able to conduct business with conventional banks. (Source: Gerrard and Cunningham [1]).

The need to establish an institution that would help to set regulatory standards and a framework for supervision of Islamic financial institutions was highlighted by Chapra and Khan [2]. The need to train Islamic bankers for developing effective rating and control systems was also stated by them.

Some of the crucial issues related to its juridical nature to facilitate effective supervision of Islamic banks were also discussed by them. This study also highlighted the facilities needed to overcome a lot of facilities that were faced by Islamic banks.

In order to find out how an Islamic bank differs from a conventional bank and to study its contribution to small and rural sectors, Islamic bank Bangladesh Limited was chosen as a case study by Alam [3]. The researcher has clearly shown through empirical evidences how interest free banks can function besides many established conventional banks and how the various financing models were operational, from the time of the inception of this interest free bank.

Haque, Lone and Thakur [4] undertook a study and explained the viability of Islamic finance in the Indian context and how it will be better for India. In the support of their claim, they used the SWOT analysis and Michal Porters five point model.They suggested the models of Islamic bank of Britain, Islamic bank of Thailand, Singapore and US so that it could be introduced in India. They also suggested that RBI can team up with reputed national and international banks in India to find out about the potential Islamic banking products.

A study by Manzoor Khalidi and Amanullah [5] for finding out about the perception of customers about Islamic banks among 100 customers of Pakistan using Z test revealed that though the respondents had adequate knowledge of the Shariah based banking system, there was doubt about the legitimacy of the Shariah compliance of the Islamic banking products and services and that religion was low in priority with regard to the choice of the bank.

Redimerio and Andrew [6] stated, "Growing and deepening market for Islamic financing is a key reason why the Islamic finance market is worth to consider for the

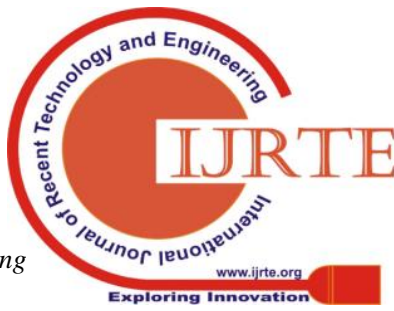


infrastructure sector. Infrastructure projects are a logical fit for Islamic finance, which is governed by Shari'ah and predicted on asset backing and shared business risk."

Sehrish Rustam et al., [7] examined the responses of 60 corporate customers of 6 Islamic banks in Pakistan to study the perception towards Islamic banking products and services. It was found that the products and services of Islamic banks have a good potential within the Pakistani corporate sector. In this study which involving only Muslims as respondents, it was found that $55 \%$ were willing to the proposal of the introduction of Islamic banking system as a replacement to conventional banking system. A majority of the respondents $(68 \%)$ felt that Islamic banks and conventional banks must focus on profit maximization so that they can survive in the competitive business environment. Also, it was perceived that religion and economics were the key factors in the bank selection criteria of Islamic banking system by $63.3 \%$ of the respondents.

Malik,A., Malik, M.S. and Shah, H., [8] analysed the Islamic banking and Finance in the West to highlight its unprecedented growth especially in the UK and the factors that lead to it. They concluded that unprecedented support from the government, fastest growing population of Muslims, petro dollar wealth of the Middle East were the prime factors for the same. They also concluded that the prospects of Islamic banking in UK was very bright, although it was not without its set of challenges.

Sultan Emir Hidayat and Nouf K Al Baward [9] conducted an exploratory research in Saudi Arabia, to study the perception of non-Muslims towards Islamic banking and found that about $48 \%$ of the respondents preferred to use Islamic banking services. This was because the Islamic banks charged less service charges in comparison to their conventional counterparts. It was also found that a large chunk of non-Muslim customers felt that the benefits of Islamic banking are good and that the services of Islamic banking are suitable in satisfying their banking needs.

\section{AWARENESS AND ATTITUDE ON ISLAMIC BANKING}

Bley and Kuehn [10] while investigating the relationship between the knowledge of university students about Islamic and conventional banks in UAE found that Muslim students preferred Islamic bank services due to religious convictions. Their sample consisted of students from various programs at the American University of Sharjah. It was found that the level of knowledge of Islamic financial terms and concepts was high among Arab Muslims when compared to non-Arabs. However, it was found that the overall banking knowledge of the students was low.

Khattak, N.A., and Kashifur Rehman [11] investigated the relationship between different demographic variables and the satisfaction and awareness of the customers of the Islamic banking industry by taking a sample of 156 respondents from different cities in Pakistan. The respondents expressed their satisfaction to some of the services and dissatisfaction with a few, although overall the customers were mostly satisfied with the Islamic banking services provided to them. It was found that the awareness level with regard to the general products but were unaware of the different Islamic financial products such as Mudarabah and ijarah.

A lot of studies have been carried out among the Malaysians. Mark Loo [12] examined the attitudinal and perceptional differences towards Islamic banking between Muslims and the rest of the customers of Islamic banks in equal numbers in Klang Valley. It was found that Muslims are supportive of Islamic banking while the others viewed Islamic banking as relevant primarily to Muslims.

A study by Ahsanul Haque [13] about the attitudinal difference of 473 customers of Islamic bank in Malaysia revealed the positive attitude towards Islamic banking of Malaysian consumers. A significant attitudinal difference was there only between Malay\&Chinese and between Chinese \& Indian. At the same time, the overall attitudes of all three races towards Islamic banking were positive. It was also found in this study that attitudinal differences existed between males and females.

Jamshidi D., Hussin, N. and Wan, H.L. [14] conducted a literature review of the potential impact of demographic items on the acceptance and usage of Islamic banking services and concluded that Islamic banking system needs to attract new customers in order to remain competitive in the market and therefore, using appropriate strategies was needed for such a banking system. Recognizing customers based on their segmentation and preferences will be a mandatory requirement, so that suitable and customized services could be provided to the customers by the banks.

Yusuf and Shamsuddin [15] carried out a study to find out about the attitude of Muslims staying outside the Islamic world by carrying out a purposive random sampling of 128 respondents from Leicester, UK. They found out that Muslims had a positive attitude towards Islamic finance as they were willing to change from the conventional system into the Islamic system of finance. Regardless of their knowledge of Islamic finance, $64 \%$ of the total respondents were willing to close their existing account and open new account with the new Islamic institution. It was also found that the levels of education did not contribute to the understanding of Islamic finance as most of them were not trained in Islamic studies.

\section{CONSUMERS' PATRONAGE TOWARDS ISLAMIC BANKING}

The bank selection criteria (patronage) towards commercial banking have been studied over a long period of time and hence an abundant literature exists. On the other hand, as far as studies of the above nature with specific reference to Islamic banks are relatively new and therefore not much literature does exist.

One of the earliest studies in Islamic banking patronage was carried out by Erol and El-Bdour[16]. This study was carried out in Jordan and investigated 434 respondents to study the attitudes, behavior and patronage factors of bank customers towards Islamic banking. It was found that the respondents were aware of the Islamic banking services and that religious motivation did not appear to be the primary criterion for the selection of Islamic banking services. They concluded that the although the religious motivation was not completely absent among the respondents, they were profit-oriented in their choice of Islamic banks due to the fact that they have been used to the conventional interest-based banking environment.

In a survey conducted in the UK to find out the patronage factors and awareness towards the Islamic methods of finance

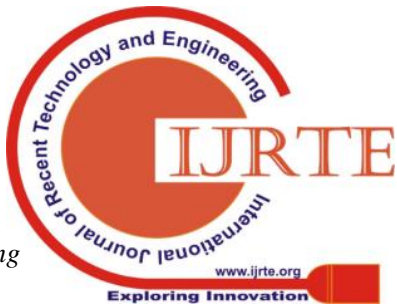


among 300 Muslims, Omar [17], it was found that the level of ignorance about the principles of Islamic finance was high. From this, it was also found that the awareness of Islamic finance methods differs between Muslims according to their country of residence.

A sample of 301 respondents of commercial bank customers in Malaysia was taken by Norafifah Ahmad, Sudin Haron and Sandra L. Planisek [18] to study their bank patronage factors. They analyzed the data using both univariate and multivariate analysis. A common perception was noticed among both Muslims and non-Muslims who patronized commercial banks. It was suggested to Islamic banks that religious factors were alone not enough to attract customers and hence the need to handle the customers by improving the quality of services offered.

Gerrard and Cunningham [1] conducted study for the differences in awareness level and attitude between Muslims and Non-Muslims towards Islamic finance in Singapore by administering a questionnaire to 190 respondents. They found that although Muslims were more knowledgeable of the meaning of the fundamental terms in Islam, all the respondents were unaware of the meaning of the Islamic financial terms. Their study also revealed that Muslims and non-Muslims have different attitude towards Islamic banking. They also concluded that there are significant differences between Muslims and others in the ranking of the bank selection criteria.

Religious and profitability were the main reasons that motivated Muslims to deposit their money with an Islamic bank. In addition to this, the Muslim customers were more influenced by the references than the non-Muslim customers. Lack of awareness of Islamic banking culture among the respondent was also found and measures were also suggested for better advertising campaigns. The study also suggested that Islamic banks should focus on fast and efficient services to the customers.

The attitude of the customers of banks and that of bankers towards Islamic banks and conventional banks was examined by Mahmood Ahmed [19] in Bangladesh using a purposive random sampling by collecting data from both primary and secondary sources. Respondents in both the categories numbered two hundred. He found that confusing notions about Islamic banking practices were there among both bankers and customers and stated that this misconception is not only because of incomplete knowledge of the fundamentals of Islamic finance but also because of relying heavily on short term trade financing.

Metawa and Almossawi [20] investigated the banking behavior of Islamic banking customers in Bahrain by surveying 300 customers of two commercial Islamic banks, which were the only such banks, then. They studied the profile of the customers, the relationship between the demographic factors and the customer usage of Islamic banking products/services, the relationship between customer satisfaction with Islamic bank products/services, satisfaction with the basic elements of the service delivery systems and the bank selection criteria. They found that the bank selection decisions by bank customers are predominantly religious decisions. While adherence to Islamic principles was the most important selection criterion, convenience of the location was found to be the least important selection criteria.
The attitude of the customers towards services and products of another Islamic bank in the Middle East called Kuwait Finance house was analyzed by Al-Sultan [21]. It was found that the main reason for the customers of KFH was the adherence to the teachings of Islam. It was also observed that there was not much of a difference between $\mathrm{KFH}$ and other banks, when considered in terms of return and cost. Contrarily, $51.7 \%$ of the respondents had preferred to deal with conventional banks due to their better service. These findings were in line with the findings of Haron, Ahmad and Planisek [18] in Singapore.

In Qatar, Metwally [22] examined the impact of demographic variables on the bank patronage of customers within a dual-banking system. This was a pioneering effort to study the relationship between these characteristics and bank patronage. It was found that females, older persons and public servants had preferred to deal with Islamic banks. Preference to Islamic banks were also high among persons with low income and a moderate level of education. Young professionals, well educated persons or highly paid public servants favoured conventional banks. Foreign banks were also preferred choice by well-educated high-income males and professionals.

Mohd Saif Noman Khan, M. Kabir Hasan and Abdullah ibneyy Shahid[23] conducted a non-probability sampling of 100 customers of 5 Islamic banks in Dhaka to study their banking behavior and found out that the most customers of Islamic banks are highly educated and have durable relationship with the banks. Income category and education of the customers have a significant role in the usage of the products and services of the banks. Another important and significant finding was that among bank selection criteria, religious principle was the key factor in choosing Islamic banks.

Ahmad, W.M.W., et al., [24] examined how the religiosity of the respondents shaped the choice of banking by using convenience sampling of 480 working Malay Muslims. They found that there are significant differences between a Muslim's religiosity level and Islamic banking as his main choice of bank. They concluded that, if Islamic banks want to retain and attract customers, they should focus on improvising their electronic services to fulfil their preferences for faster and better services.

Ahsanul Haque, Jamil Osman and Ahmad Zaki $\mathbf{H j}$ Ismail [25] studied to investigate the major factors influencing that are reflecting the customer's perception and the satisfaction on Islamic banking among the Malaysian customers and found using a Logit model that there is a significant and positive relationship of quality of services, confidence in bank, social and religious perspectives and availability of services with the customer perception about Islamic bank. These factors are may have a great role for influencing customer mind.

\section{STUDIES RELATED TO ISLAMIC BANKING IN INDIA}

Pandu, A., and Hussain, M.G., [26] studied the introduction of Islamic banking in India and suggested a legal framework. They suggested that though there are constraints in the implementation of system of

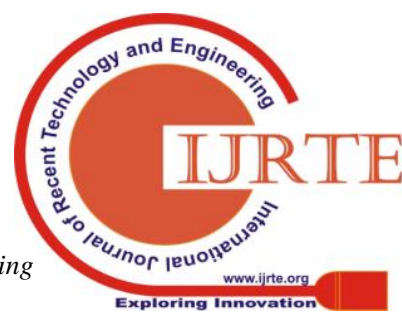


Islamic banking in India due to the provisions in the Banking Regulations Act, special provisions could be created, on the lines of provisions for NBFCs, to permit Islamic banking in India so that resources could be attracted from the Middle Eastern countries. This would be useful for the infrastructure facilities and this in turn will drive the economic growth of the country. They also suggested that initially, experimentation with existing models could be carried out and then RBI can issue licenses to global players in a phased manner to drive growth. Islamic windows could be opened in such ventures by following the examples set by secular countries like US, UK, France and Germany and then finally full-fledged Islamic banks can be made operational.

Ahangar G.B., Padder M.U.J and Ganie A.H. [27] studied the scope of Islamic banking in India and concluded that Islamic banking not only covers the needs of Muslim population but also fulfills the needs of development of all the communities. Also, India will benefit tremendously by attracting foreign direct investments in Islamic Investment funds from countries in the Middle East, thereby helping the national current account and keeping a check on the fiscal deficit. It would not only help the poor and the marginalized, but also allow small manufacturers, retailers and agricultural enterprises to access finance. It would also be able to provide equity funding for infrastructure projects such as dams, roads, electricity irrigation, and communication projects which are key factors to the development of the Indian economy.

Another study by Jeet Singh and Preeti Yadav [28] on the growth and potential of Islamic banking in India stated that Islamic banking had been misunderstood in India. It was thought of as a religious and charitable venture strictly restricted to the poor and downtrodden people among the Muslim community. In spite of the successful operations and phenomenal growth in other parts of the globe, it has failed to demystify itself in the Indian context and therefore, RBI and the Ministry of Finance should favourably re-examine the viability of Islamic banking in order to tackle the macro-economic problems faced in the country. When Islamic banking reaches Indian shores, it should be welcomed as a vibrant, progressive and modern alternative financial system and not as a outdated method of finance. It shall be in the interest of India to allow Islamic banks to operate and expand their network in the country along with the conventional banks as it promotes social well being and wealth generation.

Khan K A [29] studied the need and scope of Islamic banking in Indiavis-à- vis its present status. It was brought out that Islamic banking would result in financial instruments which are profitable and ethically motivated. He concluded that the future prospects of Islamic banking in India is very good and it should be looked at as "Interest free banking" through a broad kaleidoscope and not through a narrow religious prism.

Bhat, Z. A., [30] studied the nature, scope and feasibility of Islamic banking in India and stated that since India needs huge investments in its infrastructure building, Islamic banking can provide interest-free loans to fulfill the need and therefore, a huge potential exists for Islamic banking in India but it will need some strong policy decisions to make it a reality. Also, it needs to be positioned as a professional banking entity rather than as a religion-based banking.
Basha, S.N. and Ahmed, M. [31] studied the relevance of Islamic banking to the Indian Economy and suggested that Indian government must seriously consider adopting Islamic banking as it would solve many economic problems faced by India like suicides of farmers, shutting down of small scale industries, increase in poverty and non-inclusive growth. India may implement the same taking a cue from global examples like that of Singapore and UK.

Singh V.G., and Kaur, N. [32] studied Islamic banking in the Indian context doing a SWOT analysis for a clear view of this concept and suggested a 10 point process to make this practically viable to the people of India. They suggested that there are many challenges to be faced by Islamic banks and that they have to come out of the religious set up and offer products of wider range to be accepted and used by the audience. The banks have to not only offer products that are in compliance with the principles of Islamic finance but also ensure that they remain flexible enough to meet the growing demands of the changing mindset of the Indian customers.

A recent study by Aisha Badruddin [33] suggested that there are prejudices about Islamic banking due to the non-availability of any reports on its economic viability and its impact on the inclusive growth in India. It also suggested that efforts should be taken to give training and education in this area by including Islamic banking and finance in the curriculum of professional courses. Although the current legal framework does not permit the functioning of Islamic banks in India, it does not mean that it cannot be introduced at all. India can do well to adopt the lines of countries such as UK to modify the existing laws to govern Islamic banking business.

\section{CONCLUSION}

From the existing review of literature, it can be clearly established that not much of literature exists that have examined the bank selection criteria of Islamic banks in India involving Muslims and non-Muslims. Hence, it throws an opportunity to study the potential patronage towards Islamic banking in the Indian context.

\section{REFERENCES}

1. Gerrard, P., \& Cunningham, B. (1997). Islamic banking: A study in Singapore International Journal of Bank Marketing, 153-216.

2. Chapra, M., \& Khan, T. (2000). Regulation and Supervision of Islamic Banks. Riyadh: Islamic Research Training Institute.

3. Alam, M. (2000). Islamic banking in Bangladesh: A case study of IBBL International Journal of Islamic financial services, 10-29.

4. Haque, I., Lone, F., \& Thakur, G. (2010). Islamic banking in India: What more needed.

5. Khalidi, M. A., and Amanaullah (2010), Consumer perception of Islamic banking in Pakistan. Labuan bulletin of international business \& finance, 1-21.

6. Redimerio, \& Andrew. (2011). Will Islamic finance play a key role in funding Asia's Huge Infrastructure task? Standard and Poors.

7. Rustam, S., Bibi, S., Zaman, K., Rustam, A., \& Huq, Z. (2011). Perception of Corporate customers towards Islamic banking products and services in Pakistan. The Romanian Economic Journal, 107-123.

8. Malik, A., Malik, M. S., \& Shah, H. (2011). Analysis of Islamic banking and finance in West: from Lagging to Leading. Asian Science, 179-185.

9. Hidayat, S., \& Al Bawardi, N. (2013). Non-Muslims' perceptions towards Islamic bankingservice in Saudi Arabia. Journal of US-China Public Administration, 654-670. 
10. Bley, J., \& Kuehn, K. (2004). Conventional versus Islamic Finance: student knowledge and Perception in the United Arab Emirates. International Journal of Islamic Financial Services, 17-30.

11. Khattak, N., \& Rehman, K. (2010). Customer Satisfaction and awareness of Islamic banking system in Pakistan. African Journal of Business Management, 662-670.

12. Loo, M. (2010). Attitudes and Perception towards Islamic banking among Muslims and Non Muslims in Malaysia. International Journal of Arts and Sciences, 453-485.

13. Haque , A. (2010). Islamic Banking in Malaysia: A study on Attitudinal difference of Malaysian Customers. European Journal of Economics, Finance and Administrative services ,7- 18.

14. Jamshidi, D., Hussin , N., \& Wan, H. (2013). The potential impact of demographic items On Islamic banking services : Acceptance and usage- A literature review. International Journal of Social Science and Humanities Research, 34-39.

15. Yusuf, M., \& Shamsuddin, A. (n.d.). Muslim Consumers' attitude towards Islamic Finance Products in a non-Muslim country. Jurnal Kemanusiaan, 94-103.

16. Erol , C., \& El-Bdour, R. (1989). Attitudes, Behaviour and patronage factors of bank Customers towards Islamic banks. International Journal of Bank Marketing, 6.

17. Omer, H. S. (1992). The implication of Islamic beliefs and practices on the Islamic financial instiutions in UK: a case study of Al-Barakah International Bank UK.

18. Haron, S., Ahmad, N., \& Planisek, S. (1994). Bank Patronage factors of Muslim and non Muslim customers. International Journal of Bank Marketing, $32-40$.

19. Ahmad, M. (1998). The Attitude of bank customers and professional bankers towards Islamic And conventional banks in Bangladesh.

20. Metawa, S., \& Al Mossawi, M. (1998). Banking Behaviour of Islamic Bank customers: Perspectives and implications. International Journal of Bank Marketing, 299-313.

21. Al-Sultan, W. (1999). Financial Characteristics of interest free banks and conventional banks. Libya: University of Wollongong.

22. Metwally, M. (2002). The impact of demographic factors on consumer's selection of a particular bank within a dual banking system: a case study. Journal of International Marketin and Marketing Research, 35-44.

23. Khan, M.S.N. Hassan, M.K. Shahid, A.I. (2007). Banking Behavior of Islamic Bank Customers in Bangladesh, 159-194.

24. Ahamed, W., Rahman, A., Ali, N., \& Seman, A. (2008). Religiosity and banking selection criteria amongst Malays in malaysia. Jurnal Syariah, 279-304.

25. Haque, A., Osman, J., \& Ismail, A. (2009). Factors Influencing selection of Islamic banking: A study on Malaysian Customer Preferences. American Journal of Applied Sciences , 922-928.

26. Pandu, A., \& Hussain, M. G. (2011). Introduction of Islamic banking in India: A suggested legal framework. Intemational Joumal of Research in commerce, economics and management ,117-120.

27. Ahangar, G., Padder, M., \& Ganie, A. (2013). Islamic Banking and its scope in India. International Journal of Commerce, Business and Management, 266-269.

28. Singh, J., \& Yadav, P. (2013). Islamic Banking in India - Growth and Potential. International Journal of Marketing, Financial Services and Management Research, 59-77.

29. Khan, K.A., (2013), Emerging Islamic Banking: Its need and scope in India, Pacific Business Review International, 84-90.

30. Bhat, Z. (2013). Nature, Scope and Feasibility of Islamic Banking in India.

31. Abhinav Journal, 121-126.

32. Basha N.S., Ahmed, B.,(2013), Relevance of Islamic Banking to Indian Economy, International Journal of Research in Commerce, IT and Management, 17-20.

33. Singh, V. G, Kaur, N., (2014). Islamic Banking- In Indian Context. International journal of Emerging research in management \& Technology, 25-31.

34. Badruddin, A. (2015). Islamic Banking and Finance in India - Kosher or Myth, International Journal of Management, Innovation and Entrepreneurial Research, 1-9. 